Sintese - Rev. de Filosofia

v. 31 N. 99 (2004): 91-105

\title{
REDUCIONISMO CIENTÍFICO E ABERTURA À TRANSCENDÊNCIA
}

Hubert Lepargneur

Resumo: Este artigo relaciona o reducionismo da ciência, atividade da razão teórica, com a virtual abertura da experiência estética, mais sensível a uma realidade superior que podemos chamar de transcendente. Numa época de desconsideração metafísica, será que a arte pode substituir a filosofia no seu antigo papel de propedêutica religiosa? A própria questão merece exame filosófico. Limitamos o inquérito ao exame de dois escritos paradigmáticos, obras competentes em seus respectivos setores, o livro de Antônio R. Damásio "O erro de Descartes. Emoção, razão e o cérebro humano", o autor sendo pesquisador em neurologia, e o livro de George Steiner "Real Presences. Is there anything in what we say?", obra de um eminente ensaísta filólogo.

Palavras-chave: Filosofia, Arte, Transcendência, Religião.

Abstract: This article confronts the reductionism of science, product of theoretical reason, with the virtual aperture of aesthetical experience, more sensitive to a superior reality which may be called transcendental. In times of contempt of metaphysics, can the Art replace the traditional function of Philosophy as introduction to a religious attitude? This question is a philosophical one. We restrict the inquiry to the examination of two meaningful best-sellers from competent authors, Antônio R. Damásio, author of "Descartes' error. Emotion, reason and the human brain", and George Steiner, author of "Real Presences. Is there anything in what we say?".

Key words: Philosophy, Art, Transcendence, Religion. 
$s$ fantásticos progressos realizados em nossa época, notadamente em torno do ser humano, encontram na fé cristã algumas restri ções; não solicitam menos reflexão filosófica que deve interessar a todos. Nesta perspectiva confrontamos aqui o reducionismo científico, de essência metodológica, que aspira explicar o ser humano numa perspectiva de positivismo empírico, e outra área da cultura que seria mais propícia a introduzir à inquietação religiosa, isto é, mais aberta à transcendência do ser humano. Na primeira perspectiva usaremos o livro de A. Damásio, competente pesquisador na neurobiologia, "O erro de Descartes", por ser um best seller inteligentemente representativo da pesquisa que se chamava outrora de materialista.. Na segunda perspectiva situa-se o livro "Real Presences", de George Steiner, que ajudará a medir a contribuição potencial da música, da poesia e da arte à descoberta da transcendência, escondendo e afinal valorizando o lugar da reflexão filosófica, tema sem dúvida tradicional, mas repensado numa época que valoriza os afetos emocionais da pessoa. Escolhemos o livro de Steiner porque ele revela excepcional informação e delicadeza de tratamento na reflexão de um agnóstico declarado. Nenhuma via prova o conteúdo de uma fé religiosa, mas a via científica leva muitos intelectuais a se fechar a ela, ao responder tranqüilamente pela afirmativa à pergunta : "O processo da evolução darwiniana das espécies basta para explicar o ser humano na sua totalidade atual ?" A outra reflexão abre a perspectiva da existência de maior profundidade no mistério da transcendência humana.

É normal para a ciência proceder prudentemente mediante um jogo de indagações, hipóteses, observações e experimentações que confirmam ou rechaçam nossas idéias sobre o real, adquirindo aos poucos uma humildade que nem sempre teve ao afirmar a estrutura da realidade. Afinal ela serve para descrever condicionamentos dos funcionamentos, permitindo 0 desabrochar de uma tecnologia utilitarista. Isto vale notadamente no setor da pesquisa biomédica, hoje amplamente recompensada, mas que deixa 0 pesquisador sem respostas finais. Não cabe ao neurologista apontar para que devem servir nossas conexões sinápticas. 0 cientismo que pretende vencer pela ciência os segredos do universo e do ser humano, regrediu bastante no século XX, mas não está totalmente vencido. Apesar de enormes descobertas já efetuadas ou ainda em nossa expectativa, 0 ser humano implica um mistério que escapa à certeza científica, mas que a arte pode celebrar e a filosofia intuir. Damásio e Steiner : dois descrentes de nossa época, competentes e reputados em suas respectivas áreas, estão à procura de uma explicação do ser humano que não seja apenas literária e superficial. A confrontação de suas perspectivas parece de singular benefício tanto para a filosofia da cultura quanto para a pastoral religiosa. O livro de Damásio poderia ser substituído por alguns outros como 0 homem neuronal de Jean-Pierre Changeux, também pesquisador em neurologia; a substituição do livro de Steiner seria mais problemática em razão da invulgar penetração de seu autor. 
Seguiremos a seguinte ordem no exame dos conceitos:

1) 0 reducionismo; 2) "O erro de Descartes"; 3) A verdade do holismo; 4) A modernidade, ruptura entre palavra e coisa; 5) A música introdutora de transcendência; 6) 0 sentido desemboca em perspectiva religiosa; 7) Entre filosofia e mística : a teologia apofática; 8) Conclusão.

\section{O reducionismo: o cérebro produz a mente, que produz o pensamento}

"O erro de Descartes" é expressão paradigmática do reducionismo da ciência, cuja versão prudente é apenas metodológica. A ambição do autor é relacionar não apenas o cérebro, órgão do pensar, com a emoção e a sensibilidade, mas também o cérebro com a totalidade dos órgãos do corpo humano, sem apelar para qualquer suspeita de transcendência do espírito humano em relação ao comportamento dos outros primatas evoluídos. 0 Sapiens sapiens aparece assim puro produto da evolução das espécies : 0 pensamento humano brotaria da vida com a mesma naturalidade que a vida surgiu da matéria, ainda que a vida seja ainda um dos conceitos mais enigmáticos que tenhamos. A filosofia do ser humano pode se interrogar por que a Igreja acredita numa criação especial da alma humana, portanto na insuficiência da evolução natural das espécies, o termo alma_podendo ser substituído por mente ou outro parecido. Permanece a indagação de saber se a ciência como ciência poderia um dia reconhecer que nunca chegará a elucidar a totalidade das capacidades da mente humana. Provavelmente não, porque a liberdade tem chance de ficar sempre misteriosa, sob pena de cair num determinismo que transtornaria a ética e a cultura humana. É concebível que uma ciência possa reconhecer seus limites absolutos; é mais difícil conceber que não possa haver outra ciência para preencher o vazio. Isto implica saber se a totalidade da experiência humana é tematizável.

O subtítulo do livro em pauta faz apelo à "Emoção, razão e o cérebro humano". Não se refere explicitamente à mente, que mais nos interessaria. No entanto, qual é o estatuto conferido à mente nesta obra ? Este conceito nunca é definido, mas é repetidamente apontado qual é seu embasamento : o cérebro, com a integralidade de suas conexões orgânicas e ambientais. A expressão é sempre : "O cérebro produz a mente." Como ? Não se sabe. Trata-se de uma produção ou evolução bionatural, sem a menor referência a uma eventual transcendência. 0 domínio da simbólica, da analogia, para não falar em sobrenatural ou em nova criação, é totalmente estranho neste contexto. "O produto mais precioso do cérebro é a mente" (287), o cérebro é produtor da mente ( 292). A explicação procurada por Damásio não é filosófica nem religiosa, apenas fisiológica : trata-se de descrever o design 
de grande escala que integraria muitos circuitos micro-estruturais e macroestruturais (292).

Ao combater o mito do "homúnculo" que presidiria à consciência (273), 0 autor combate a noção cristã e pré-cristã de alma, mente humana na psicologia. "A referência de base do corpo eliminaria a necessidade de atribuir a um homúnculo a produção da subjetividade" (266). Bastaria que as representações primordiais do corpo proporcionassem o núcleo da representação neural do eu (266). A subjetividade emergiria quando o cérebro tivesse produzido as imagens de um objeto, as imagens do organismo reagindo a este objeto $e$ "a imagem do organismo no ato de perceber $e$ responder ao objeto" (273). Entretanto a descrição da suposta emergência da consciência no tecido neuronal produtor de imagens não informa sobre a especificidade humana da consciência, capaz de razão, de abstração, de raciocínio e de transcendência.

\section{"O erro de Descartes"}

A total redução do ser humano expressa neste livro não percebe, da mente ou na mente, senão seus fundamentos cerebrais, neurobiológicos, estendidos ao corpo inteiro. Ignora-se o que faz que o homem seja um animal radicalmente diferente dos outros, capaz de auto-análise crítica. Reduzir a antropologia à fisiologia é admissível e até precioso como aprofundamento de um setor particular do ser humano, com a condição de abrir a perspectiva sobre um nível mais integrador de compreensão específica que possa nos esclarecer sobre a natureza e a função da mente. Não estamos seguros de que o livro justifica seu título porque, para as normas do "Discurso do M étodo" de Descartes, é indispensável proceder a uma enumeração completa dos fatores cuja análise precisa de ulterior síntese. É precisamente a insuficiência das análises na explicação dos fenômenos que suscitou 0 atual movimento de holismo: se o cosmo é um todo, também o é o ser humano. Não se trata de justificar uma independência da mente da fisiologia cerebral e corporal, mas Damásio deixa de levar suficientemente em conta a relação que existe entre as percepções, emoções, conexões neurológicas ou viscerais (assunto principal do livro em pauta) e a atividade da inteligência, o poder da cognição, se não da liberdade. 0 erro filosófico de Descartes, que hipotecou o devir filosófico, sem obscurecer 0 aporte positivo de Descartes na fundação da filosofia moderna, deve ser colocado no seu contexto cultural que ignorava todos os nossos instrumentos de investigação da fisiologia humana, inclusive por meio de imagens de transparência in vivo.

0 "penso, portanto existo" não responde à procura de uma fundação lógica da filosofia (como se lê à p. 280) mas, mais exatamente, à procura de 
uma fundamentação segura, supondo, é verdade, certa transcendência do espírito sobre a matéria do corpo. Descartes não se sente totalmente escravo e preso do corpóreo. 0 processo do cartesianismo como independência do espírito em relação ao corpo pode ser considerado como concluído. A partir da hipótese de que seja falso tudo o que ele percebe ou acredita saber, Descartes (1596-1650), à procura de uma certeza inicial e fundamental, da qual não possa duvidar, chega a esta intuição genial: "Penso, portanto existo". Disso ele pode deduzir que, nele, existe algo que tem o papel de eu, de sujeito, portanto de um ser realmente existente (Discurso do M étodo IV; Meditações metafísicas II). Seu erro é subseqüente: acreditar que sua mente pode autoconscientizar-se independentemente da participação do corpo; mas, que o corpo seja real ou ilusório, não resta dúvida que a autoafirmação de si possui valor próprio. "Eu não disse que eu seja uma alma, mas apenas algo (une chose) que pensa, e dei a esta realidade que pensa o nome de espírito ou de entendimento ou de razão" (Meditações metafísicas, Observações sobre as sétimas objeções). O chamado dualismo cartesiano foi endurecido após o mestre e deve ser revisto à luz das Notae in programma (resposta a Regius), nas quais se lê : "Quem entendeu até onde se estendem nossos sentidos, e o que eles trazem até à faculdade que temos de pensar ...". Ao descobrir hoje, com Edgar Morin e outros, o sério da complexidade dos fenômenos, nem sempre é fácil observar a regra cartesiana do alistamento completo dos fatores influentes no objeto estudado. Na história da filosofia encontramos, de um lado, La Mettrie, para quem o pensamento é uma propriedade da matéria e, do outro lado, Leibniz, para quem a matéria, por si mesma é incapaz de pensar. Bergson matiza: 0 pensamento é, em grande parte, independente do cérebro. Mas o materialismo de Damásio não é isolado entre pesquisadores modernos: temos mencionado Changeux, que foi presidente do Comitê Francês de Bioética e defende a idéia de que a atividade mental não é nada mais que influxos nervosos, as imagens mentais sendo materiais. Merleau-Ponty não é menos simplificador quando opina que a distinção alma-corpo não tem mais razão de ser. A estreita vinculação da mente e da fisiologia não legitima uma total fusão ou confusão.

Será Damásio mais cauteloso quando escreve: "É um fato incontestável que o pensamento provém do cérebro" (281), como a bílis do fígado? Ou ao pretender que "a questão principal" neste debate é "considerar as razões por que os neurônios conseguem pensar tão bem" (281)? A questão principal pode antes indagar como 0 jogo dos neurônios e das redes fisiológicas atravessando todo o corpo consegue justificar a apreensão de valores éticos e estéticos, para não dizer transcendentes e religiosos. Não será simplista afirmar que "o sistema imunológico, o hipotálamo, os córtices frontais ventromediais e a Declaração dos Direitos do Homem têm na raiz a mesma causa" (294)? Outra ordem de causa pode ter intervindo e sua importância ter superado as conexões de sinapses. 


\section{A verdade do holismo}

A enumeração completa dos fatores atinentes ao fenômeno estudado tomou particular destaque e urgência com o contexto cultural moderno do holismo. Acreditar com Searle e outros biologistas reducionistas que 0 processo evolucionista da matéria e da vida é suficiente para explicar a integralidade do ser humano não passa de colossal engano. Até o descrente Francis Fukuyama, ao examinar no livro "Our posthuman Future. Consequences of the Biotechnology Revolution" as fundamentações da famosa "dignidade humana", admite "um salto das partes ao todo que, em última análise, deve constituir a base da dignidade humana, conceito crível, ainda sem passar pelos postulados religiosos da Igreja" (253). Muitos pesquisadores da Inteligência Artificial afirmam "que a consciência é uma propriedade emergente de um certo tipo de computador complexo. $M$ as isto não passa de uma hipótese desprovida de provas, fundada sobre uma analogia com outros sistemas complexos. Ninguém viu uma consciência aparecer em condições experimentais..." (Idem). Searle é representativo de um grupo de cientistas que acreditam que a consciência é uma propriedade do cérebro, mediante a ativação correta de certas sinapses, conexões de neurotransmissores, que a neurologia explicará num futuro desejado próximo. É o caminho que Ihes parece necessário para evitar uma ontologia chamada dualista, concebida como antagônica ao atual saber científico. Fukuyama é modesto ao concluir este ponto: "O problema da aparição da consciência não remete a nenhuma intervenção de Deus. Inversamente, não a exclui tampouco".

A procura de um gene promotor da consciência ou da inteligência ou da palavra ou da ética do ser humano não resultou em conclusão satisfatória, notadamente porque o ser humano exige, em sua fundamentação biológica, um conjunto de genes e determinações que condicionam, antes de afetar, a consciência, a razão, a elocução, as emoções, a capacidade ética etc. A dignidade humana que disso resulta, até para o descrente, não se reduz a um só fator, a uma única qualificação ou capacidade. A liberdade suposta pela ética exige não apenas o discernimento de uma razão alimentada por um aparelho cognitivo bem equipado, mas também o jogo de amplas emoções alternativas, a relação da subjetividade individual com outras subjetividades personalizadas etc. Tudo isso é algo que a neuropsicologia ou neuropsiquiatria se recusa a designar e até a pressentir e que a fé cristã conhece desde suas origens.

Alterando a desconfiança da encíclica Humani generis de Pio XII, João Paulo II reconheceu, meio século depois, que "novos conhecimentos levaram ao reconhecimento da teoria da evolução, que é mais do que uma hipótese" (Mensagem de 1996 à Academia Pontifícia das Ciências). Prossegue o Papa ao reparar que a aceitação de uma filiação orgânica de nosso corpo em 
relação à evolução animal não deve ocultar um "hiato ontológico" que corresponde a uma intervenção direta de Deus; ela ocorreu ou começou a acontecer no decorrer dos cinco milhões de anos que separam nossos antepassados e a aparição do Homo sapiens sapiens que somos. Filhos de Adão, mas também de Cro-Magnon. Comentário de Fukuyama: "A ciência natural moderna poderia descobrir o processo cronológico e explicar suas correlações materiais, mas não explicou ainda o que é a alma nem como chegou à existência" (240). O Papa acha que esta explicação naturalista nunca ocorrerá porque é impossível. Portanto "as teorias evolucionistas que consideram, de acordo com as filosofias que as inspiram, que o espírito é uma emanação das forças da natureza viva são incompatíveis com a verdade do ser humano" (João Paulo II).

Confissão de Fukuyama: "Se muitos cientistas descartam ter algo a aprender da Igreja, o Papa apontou uma real fraqueza no estado atual da teoria evolucionista, à que os cientistas deveriam refletir. A ciência natural moderna explicou muito menos que eles acreditam o que significa o fato de ser homem" (240). As etapas da evolução animal para chegar, após o fracasso de muitos impasses (inclusive diversas espécies de Homo, desde 0 ergaster, passando pela aparição e o inexplicado sumiço dos neandertalianos), ao Sapiens sapiens que somos e pretendemos explicar, exigiram muito tempo e ensaios (tenha havido, ou não, uma finalização que a paleoantropologia nega fortemente). Nossas hipóteses, concebidas após outras hipóteses contestadas por novos achados, nunca chegam a explicar a aparição do mais específico do ser humano, como o Papa apontou e como contextualizamos na cultura filosófico-científica. Ainda neste ponto a conclusão de Fukuyama está certa: "O problema reside na própria metodologia do reducionismo na ambição de compreender sistemas complexos, particularmente sistemas biológicos" (241). Se uma metodologia que abrange desde cedo a totalidade do ser em exame é exigência para entender o papel do ser vivo, quanto mais esta altura holística se impõe tratando-se do ser humano e de sua inteligência. Edgar Morin passou décadas explicando que, por necessária que seja a análise, o desafio da complexidade exige do observador ampliar seu horizonte para situar cada parte no conjunto do ser questionado (Hassing, 224-226). A suprema complexidade nesta terra está em nós e ao nosso redor: a do ser humano, porque ninguém explica como as sinapses, que articulam neurônios e movimentam partículas atômicas, podem chegar, sem intervenção totalmente externa, superando a "emergência" costumeira, "a formular, discutir e modificar normas abstratas da justiça" (Fukuyama, 245).

Os autores que imaginam que a aliança entre as neurociências e a informática pode chegar a construir robôs conscientes divagam na utopia. Cabe à dimensão filosófica da reflexão sobre o progresso dos autômatos revelar ao materialismo arcaico qual pode ser o estatuto otológico de uma consciência humana, irredutível aos sistemas de feedback mais sofisticados. 
"Os estados mentais subjetivos, gerados segundo processos biológicos materiais, parecem depender de uma ordem diferente e não material, em relação aos outros fenômenos" (Fukuyama, 247).

\section{A modernidade, ruptura entre palavra e coisa}

A modernidade, que realça os incontestáveis avanços da tecno-ciência, versa também numa supervalorização da emotividade, promotora da expansão da diversão. Estas duas vias raramente encontram Deus no caminho. Em contraposição, reparamos em escritos de G. Steiner, filósofo e lingüista, uma inesperada intuição da vinculação religiosa de setores escolhidos da cultura moderna (270). Afirma a afinidade fundamental, ainda que implícita, entre a criação artística e a transcendência metafísica e religiosa. Desprovido de religião definida, este autor percebe uma relação forte entre a excepcional crueldade, a violência, do século XX e 0 afastamento de Deus. “ $\mathrm{Na}$ arte e no pensamento recente, não é exatamente 0 esquecimento de Deus que opera, mas um teísmo negativo, um sentimento particularmente vivo da ausência de Deus, mais exatamente de seu afastamento (retrait)". "O Outro não é mais encarnado; deixa atrás de si, ora vestígios seculares incertos, ora um vazio ainda ecoando sua saída. Nossas formas estéticas exploram o vazio e a liberdade que decorrem do sumiço do messiânico e do divino" (271).

0 realismo antigo era fundamentado sobre a aliança que parecia natural entre as palavras e as coisas do mundo, aliança produtora de sentido na avaliação humana. Steiner define a modernidade pela crise do sentido que ocorreu em seguida à ruptura deste acordo natural entre as palavras e as realidades, ruptura que se teria iniciado entre os anos 1870 e 1930. Não houve novo Descartes para remediar radicalmente a esta dúvida. Dos antigos gregos até os meados do século XIX, a humanidade ocidental civilizada vivia sob o regime do Logos, isto é, do ser. A ruptura da modernidade foi, aos olhos de Steiner, uma das muito raras autênticas revoluções do espírito. Ela constou numa guinada antropocêntrica que promove, de modo sartriano, o ser humano como a fonte do valor e do sentido, operação que a ciência é incapaz de realizar. A Igreja percebeu aos poucos seus efeitos destrutivos, sem necessariamente situar exatamente sua origem. As tentativas de racionalização da História, de Hegel a Comte, caem num anacronismo insensato. 0 formalismo lingüístico pode ser ele mesmo considerado como um anacronismo, na medida em que a nova hermenêutica liberava o ser humano da prisão da linguagem, libertação profeticamente antecipada pela poesia e as artes em geral. 
Por trás desta evolução-revolução desenvolve-se um agnosticismo que chega de vez em quando ao ateísmo. Por falta de Logos na presidência da inteligibilidade do mundo, todo sentido vacila e as tentativas de reconstrução da Torre de Babel propiciam o que vemos. Sem Logos, sem divindade, cai o Absoluto cuja irradiação assegurava a firmeza do sentido de nossos discursos. Nossas aspirações têm de se tornar mais modestas, ao ponto que Steiner estima que a audição da música (pensando na dita clássica) "é o único tempo livre que nos seja concedido até a morte" (236). A intuição de Lévi-Strauss não difere muito quando este etnólogo diz ter a convicção de que as melodias constituem o supremo mistério das ciências do homem. $\mathrm{Na}$ dissolução da razão que prevalecia no Iluminismo, de Nietzsche a Freud, de Lacan a Foucault e Derrida, a deconstrução poupa a intuição como salva-vida gentilmente oferecido pela estética. Toda aspiração religiosa ao Absoluto está suspeita de ser infantil ou de cair logo no dogmatismo. A música não define nada, não impõe nenhum dogma. Alimenta a religiosidade órfã da religião. Seria apressado interpretar este movimento como sendo sempre um ateísmo inconfessado. Steiner pressente nele a sombra da transcendência de um Deus inefável. Voltaremos sobre a inefabilidade do Nome, do Tetragrama israelita, da não figuração da Alá, balizas da teologia negativa.

\section{A música, introdutora de transcendência}

Após ter analisado a poesia e a arte em geral, Steiner, incerto sobre qual seria sua divindade, caso devesse escolher, opera uma opção intuitiva para a Criação e afirma existir certa continuidade participativa de toda criação parcelar, artística ou outra, humana, com esta suposta criação primitiva, que produziu o ser (Steiner escreveu um livro sobre Heidegger). A tal ponto que não the parece existir uma visão inteligível de nossa experiência estética ou de nossa responsabilidade (ética) sem esta participação (253).

No cerne da experiência estética, Steiner situa a música, porque "a música põe nosso ser de homem ou de mulher em contato com aquilo que transcende o dizível, aquilo que ultrapassa o analisável. Os sentidos do sentido da música são transcendentes. Foi por muito tempo, e ainda é, a teologia não escrita daqueles que não têm ou rejeitam toda crença formal. Para muitos, a religião tornou-se a música na qual eles acreditam. Nos êxtases do pop ou do rock, esta relação é aguda (259) ... num momento da história que ridiculiza o que é nitidamente teologia" (265). Mas, o autor sabe que abandonar 0 absoluto místico-religioso é deixar a âncora que torna este mundo compreensível e relativamente amical, pelo menos domesticável. Disso decorrem certa crise do próprio empirismo e as dúvidas sobre 0 alcance da ciência. Nada disso facilita a paz dos espíritos e do mundo. 
Steiner acredita num além, numa transcendência, que ninguém é capaz de definir para ele, mas este pano de fundo lhe parece indispensável para conferir sentido ao sentido, vida à alma, perspectiva e densidade à emoção estética. Steiner não gosta de evocar diretamente Deus, mas perceber na divindade o sentido do sentido reflete um senso da transcendência que certo pietismo cristão parece ter perdido. Até as Luzes, quase todos os grandes dramaturgos, poetas e filósofos acreditaram numa população celestial ou numa divindade. Desde o monoteísmo precursor de Zaratustra. Toda criação humana pode co-participar da criação primitiva, dando prosseguimento à fecundidade de uma fonte transcendente que escapa a nosso positivismo imediatista. No mesmo sentido, Derrida, o deconstrutor, afirmou que a nossa época, época do sinal segundo ele, é essencial mas inconscientemente teológica. São curiosas confissões, em contexto de abandono da metafísica e das religiões. Steiner, no entanto, insiste: "Deus, Pai do sentido, sob Sua forma de autor, desapareceu do jogo: não existe mais um juiz privilegiado, um intérprete que possa determinar e comunicar a verdade, as intuições autênticas contidas na matéria" (157). Exit o papel doutrinal e infalível da profissão católica. "Somos hoje órfãos, mas livres, no espaço do a-Logos" (157). Perdendo balizas, normas seguras, objetivos predeterminados, a verdade arrisca dissolver-se na futilidade dos desejos, fora débeis comprovações experimentais da tecno-ciência. Sem referência ao Brasil, Steiner conclui: "Se se conceder à imensa maioria da humanidade a liberdade de escolha, ela preferirá a Ésquilo o futebol, as telenovelas ou a loteria" (93). Entretanto, o Carnaval salva o sentido do mito e o jogo permanece importante para Steiner. Este autor, porém, não se conforma com um mundo dissolvido na futilidade, porque, através da criação artística ele acata a consciência espontânea da presença imanente e fundante da divindade no relacionamento do ser humano com seu ambiente natural ou elaborado.

\section{O sentido desemboca em perspectiva religiosa}

"A história, quando é história da história, é história do sentido" (117) ou da carência de sentido. Para que haja sentido no homem e no mundo, deve haver um liame de comunicação que aspire à verdade, à alguma confiança na expressão verbal. Mas o século XX viu aparecer uma tal força da lingüística que certa escola concentrou todo o sentido na coerência do círculo verbal, o que era atrofiar a capacidade evocadora da palavra como sinal. A poesia e a arte em geral são tentativas, valorizadas por uns, desprezadas por outros, de romper o círculo hermenêutico do pleonasmo, do jardim artificial onde tudo parece entendido ou provado numa suprema coerência, mas carece de profundidade significativa, de transcendência. A men- 
sagem de Steiner é de libertar o sentido da prisão das palavras, dos discursos corretos, da lingüística estruturalista, do formalismo verbal. Mas não será este um salto inseguro, no desconhecido? A dúvida vem de longe; já a perenidade do sentido através da identidade das palavras, questionada por Montaigne, é derrubada por Steiner: toda compreensão de um sinal é recriação de seu sentido, sem nenhuma garantia de coincidência com 0 sentido do autor primitivo. Steiner acredita que dificilmente o dogma estabiliza o sentido de um texto, apenas impõe determinada interpretação. $\mathrm{Na}$ interpretação de uma peça de música, cada músico que a interpreta põe algo de sua personalidade na sua recriação, se não todos os maestros de orquestra seriam trocáveis. Para evitar a valsa dos sentidos, já Pascal Iançava a âncora da veracidade de Deus. Malebranche e outros (sem omitirmos Descartes, na sua terceira Meditação) não fizeram outra coisa: Deus, em quem confiamos soberanamente pela fé, assume a correspondência entre nossas sensações e a realidade do mundo criado por Ele. Mas isto foi pensamento de ontem.

Não é o menor mérito de Steiner sondar um além da experiência pragmática ou da indução racional, na direção de uma metafísica que ele admite implicitamente e de uma religião que ele rejeita explicitamente como opção pessoal: neste além ele situa experiências culturais brotando de uma intuição capaz de predispor à aceitação de uma fé religiosa. "O artista, o poeta, o músico, traduzem esta intuição numa forma vivenciada. Eles fazem a hipótese de uma metafísica prolongável até o religioso. A transcendência em relação a toda verificação implicada nesta hipótese, é uma disciplina do não-saber ... Em resumo, creio que a poesia, a arte e a música nos conectam diretamente com aquilo que, em nosso ser, não é nosso" (268-9). Wittgenstein era muito músico para acreditar realmente que nossos limites pessoais são os de nossa linguagem. Toda arte e toda literatura começam na imanência; mas não param aí. Para Steiner as questões mais profundas versam sobre as raízes e 0 alcance da poesia, da música, da arte, e são intrinsecamente questões teológicas e não apenas psicológicas ou filosóficas. Isto esclarece a sentença de outro eminente descrente, D.H. Lawrence: "É preciso ser terrivelmente religioso para ser artista". Terrivelmente religioso ou anti-religioso.

Religiosos ou não, não são os cientistas que nos levam mais próximo ao fundo do ser humano, nem talvez os psicanalistas, mais perto do enigma do ser pessoal; são, pelo menos para Steiner, os artistas das palavras, das formas e dos sons. 0 poeta Yeats 0 entendeu: "Nenhum homem saberia criar como fizeram Shakespeare, Homero, Sófocles, se não acreditasse com toda a sua carne e todas as suas fibras, que a alma do homem é imortal". Além de ser grande conhecedor de Shakespeare, Steiner escreveu sobre Antígona um livro que consideramos como sua obra-prima.

Podemos nos perguntar por que, após conferir um indispensável embasamento religioso à arte, que culmina para ele na música clássica, 
Steiner não abraçou religião nenhuma. Uma razão, que cabe neste estudo e que o livro em pauta evidencia, é a recusa de um dogmatismo que define uma vez por todas, autoritariamente, o sentido de uma proposição. Para ele todo leitor, tendo visitado um museu, tendo ouvido a interpretação de uma grande obra musical, participa numa co-criação que pode variar, sem limites conhecidos. Ele lembra que, apenas no campo da literatura moderna, avalia-se a produção das teses de doutoramento nas universidades russas e ocidentais em umas 30.000 (46). Ainda, apenas no espaço das humanidades, a biblioteca de uma Universidade que pretende atualizar-se e teria os meios por isso, deveria receber e classificar de três a quatro mil periódicos. Apenas a lista dos comentários do Faust de Goethe compreende quatro volumes espessos e ficou desatualizada desde que saiu a público. Sobre Hamlet, desde o fim dos anos 1780, mais de 25.000 livros, ensaios, artigos, atas de colóquios pretendem expor, com notória diversidade, os sentidos e interpretações da obra. Nem se pode contabilizar os comentários da Divina Comédia. Apenas para celebrar o centenário da morte de Victor Hugo, em 1985, houve 35 congressos. Ainda antes que saísse uma revista e boletins consagrados à obra de Faulkner, mais de mil teses e artigos entendiam apresentar explicações. Os mitos têm uma flexibilidade na sua transmissão oral que permite interpretações variadas. Se uma forte corrente do Islamismo se decide, um dia, entrar na crítica textual do Corão, as próprias palavras de Alá, pronunciadas pelo arcanjo Gabriel, vacilarão.

Steiner chega a falar em "plenitude do sentido" (267), expressão que parece tirada da Cristologia paulina e revela as limitações de um cientismo pragmático que, na antropologia, limitar-se-ia às conexões neuronais e derivados. 0 reducionismo científico acharia inconveniente, positivamente incorreto, o que Steiner admite, a saber "uma impulsão fundamental do espírito humano para explorar possibilidades de sentido e de verdade que escapam à percepção ou a demonstrações empíricas. 0 que predomina no moto espiritual é a implicação, direta ou indireta, da dimensão sobrenatural, além das fronteiras da razão" (267). Interessa aí a aceitação de uma zona do real que escapa a nossa experiência superficial, ainda que rigorosamente comprovada, ilustrando o dito do inglês Thomas Browne: "Somos homens, sem saber como".

\section{Entre filosofia e mística: a teologia apofática}

Filosofia e religião procuram o sentido. Numa entrevista que deu a briIhante jornalista Françoise Giroud pouco antes de desaparecer em 2003, aos 85 anos, em plena atividade ("a morte é uma formalidade pela qual é preciso passar"), esta escritora reconheceu que nunca foi realmente crente. 
Interrogada sobre a atual procura de sentido que parece animar certos meios, respondeu : "Procura de sentido? Mas a vida não tem sentido. Porque a vida deveria ter sentido? No entanto a gente pode conferir sentido à própria vida...". Esta reflexão, por parte de alguém que observou atentamente sua época e desempenhou papéis politicamente relevantes, chama a atenção sobre a indagação: De onde vem o sentido? Da elaboração filosófica ou da recepção religiosa da mensagem da divindade? Posse inata a ser descoberta ou aquisição voluntarista?

A teologia apofática é o nó em que convergem filosofia, mística e teologia. Numa época de dúvidas sobre todo dogmatismo, seu realce permitiria distinguir um ateísmo materialista, um tanto envergonhado de se refugiar num positivismo científico insensível à onda moderna da religiosidade, e uma sensibilidade mais profunda quanto à inefabilidade do Ser. 0 desafio não atinge apenas a teologia, mas interessa uma concepção ampla da filosofia como analista do pensar humano e da cultura. 0 divórcio que caracteriza a modernidade, a saber entre 0 Logos (linguagem) e a realidade (o Ser), além de jogar sobre o saber humano, mesmo científico, uma suspeita de incontornável relativismo, solapa também a vinculação da ética com a razão (técnica) como salientou diversas vezes Henrique de Lima Vaz. Com Steiner e outros, a teologia apofática, que é mística, faz estourar os limites da linguagem verbal em que uma filosofia analítica, exageradamente estruturalista, formalista e empírica, tinha a tendência de aprisionar o universo cognitivo do ser humano. A onda atual empresta o vector da emoção como chave de sua síntese psicológica e cultural, mas o que lemos em Steiner sobre a arte revela um horizonte mais rico e mais propício ao leque das transcendências. Se a hermenêutica saiu da interpretação da linguagem, ela pode e deve prolongar-se na filosofia da arte, sem conceder exageradamente a uma moda transitória.

Quer o analista parta do aprofundamento da música, como criação e interpretação, ou da crítica à pobreza da palavra "Deus" para exprimir o supremo mistério do Ser, ele anda num terreno preparado por milênios de reflexão filosófica. Os cristãos das origens foram acusados de serem ateus. Mas frente a qualquer ateísmo temos de perguntar: qual é a divindade que se recusa? Nisso está a perplexidade da teologia apofática como mão estendida à sabedoria filosófica. 0 mestre zen Jacques Brosse, autor de livros apreciados sobre as religiões e que não esconde suas simpatias pelo catolicismo e a Santa Virgem, manifesta profunda reticência em definir Deus. Nisso, herda uma tradição que remonta a, pelo menos, Plotino, que evitou usar o termo Deus, preferindo falar em Um e em Princípio. Cinco séculos depois, Dionísio, o dito Aeropagita, enveredou na mesma perplexidade. No século XIV, o anônimo inglês conhecido pelo título de "A nuvem do desconhecimento", adotado pelo Catolicismo como um clássico do misticismo, contem, no capítulo VI, este trecho: "O discípulo perguntou ao mestre: Como é Deus? Como chamá-lo? Quem ele é? Ao que o mestre respondeu: 
Nisto só posso dizer uma coisa: não sei. Não sei quem Ele é. Tudo o que posso fazer é tocar com o fraco aguilhão do amor sobre a nuvem de desconhecimento que existe entre mim e meu Deus". Além de Mestre Eckhart, que distingue Deus e a insondável Divindade, temos, no século XV, 0 cardeal Nicolau de Cusa, que evitou também excessivas pretensões no conhecimento do Princípio supremo. A reticência culmina em religiões asiáticas como o budismo.

Se filosofia, sabedoria e religião mal se distinguem em religiões tradicionais da Ásia, o catolicismo valorizou insistentemente a filosofia como sua grande aliada. As encíclicas referem-se mais à filosofia que à ciência quando aludem aos puros produtos da mente, levando a questão do tratamento das emoções quando tomam importância cultural que destrona a antiga metafísica. Mas isso é outro assunto.

\section{Conclusão}

A antropologia não deixa de se enriquecer, ano após ano, com a biomedicina e atualmente com os progressos da neurofisiologia. Este processo reclama reflexão filosófica informada com as novas conquistas atinentes ao cérebro e ao pensar: pode-se passar dos genes às proteínas e das sinapses ao pensar, da mesma maneira? Nos últimos vinte anos importantes descobertas e progressos foram igualmente conseguidos na paleoantropologia, mas os exames de ossos pouco informam sobre a evolução das capacidades mentais em milênios passados; a antropologia genética introduziu nova revolução em nossa árvore genealógica, mas nos deixa ignorantes sobre a passagem da animalidade evoluída à posse do espírito imortal evocado pelo Cristianismo. Os progressos da etologia reduziram bastante as distancias entre o Sapiens sapiens que somos, e o chimpanzé, o animal ainda vivo cujo DNA é mais próximo do nosso. Cientistas presos em seu reducionismo acham que o progresso da ciência explicará um dia que o hiato é apenas obra da evolução natural; a fé cristã afirma que existe um hiato mais sério, que implica nova intervenção divina. Não cabe à filosofia resolver a divergência, porque a fé religiosa comportará sempre um salto além dos dados empíricos sobre os quais se apóiam ciência e filosofia. J. A. Mac Dowell mostrou que 0 verdadeiro Deus não pode fazer parte da explicação racional do mundo. 0 que a vivência estética carece em matéria de rigor racional, em comparação com a ciência, está mais do que compensado, em outra perspectiva, pela sua eventual abertura à transcendência, ainda que esta comportasse vários níveis. Tanto para Damásio quanto para Steiner, 0 intelecto, promovido em espírito nas antropologias religiosas, está vinculado de maneira inexplicada à dupla alma-corpo, que não passa de corpo animado, isto é, de corpo no qual se processou a química e a genética da 
vida. Isto lembra a obra de Aristóteles por quem a alma é inseparável do corpo, mas que não exclui, como estranhamente ao lado, a operação da um intelecto que seria eterna, assim como lembrou Fernando Rey Puente. Resta à filosofia reconhecer as limitações da atividade científica e de seus frutos, questionar os limites concebíveis do progresso científico, e, talvez, sondar na cultura vigente onde se situam preparações, se não de maior audiência, pelo menos, de maior seriedade.

\section{Bibliografia}

CHANGEUX, J.-P., L'homme neuronal, Paris: Fayard, 1983.

DAM ÁSIO, A.R., O erro de Descartes. Emoção, razão e cérebro humano, São Paulo: Companhia das Letras, 1996. (Tít. or.: Descartes'error. Emotion, reason and the human brain, New York, 1994).

FUKUYAMA, F., La fin de l'homme. Les conséquences de la révolution biotechnique, Paris: La Table Ronde, 2002 (a paginação no artigo remete a esta edição). (Tít. or.: Our Posthuman Future. Consequences of the Biotechnology Revolution, New York: Farrar, Straus \& Giroux).

HASSING, R.F., Final causality in nature and human affairs, Washington D.C.: Catholic University Press, 1997.

MAC DOWELL, J.A., A experiência de Deus à luz da experiência transcendental do espírito humano, Síntese 29 (2002) 5-34.

MONTAIGNE, Ensaios, Da experiência III, 13.

PICQ, P. - LEMIRE, L., À la recherche de I'homme, Paris: Nil, 2002.

PUENTE, F.R., A morte como término, mas não como finalidade da vida em Aristóteles, Síntese 29 (2002) 95-102.

STEINER, G., Réelles présences. Les arts du sens, Paris: Gallimard, 1991 (a paginação no artigo remete a esta edição). (Tít. or.: Real presences. Is there anything in what we say?, London: Faber and Faber, 1991).

Endereço do Autor:

Av. Pompéia, 1214

05022-001 São Paulo - SP 